\title{
Earlier post-operative hypocortisolemia may predict durable remission from Cushing's disease
}

\author{
Natasha Ironside 1,2, Gregoire Chatain ${ }^{3}$, David Asuzu1,4, Sarah Benzo', Maya Lodish5, Susmeeta Sharma ${ }^{6}$, \\ Lynnette Nieman ${ }^{7}$, Constantine A Stratakis ${ }^{5}$, Russell R Lonser ${ }^{8}$ and Prashant Chittiboina ${ }^{1,3}$
}

'Surgical Neurology Branch, National Institute of Neurological Diseases and Stroke, Bethesda, Maryland, USA, ${ }^{2}$ Department of Neurosurgery, Auckland City Hospital, Auckland, New Zealand, ${ }^{3}$ Neurosurgery Unit for Pituitary and Inheritable Diseases, National Institute of Neurological Diseases and Stroke, Bethesda, Maryland, USA, ${ }^{4}$ Yale School of Medicine, New Haven, Connecticut, USA, ${ }^{5}$ Section on Endocrinology and Genetics, Eunice Kennedy Shriver National Institute of Child Health and Human Development, Bethesda, Maryland, USA, ${ }^{6}$ Pituitary Endocrinology Section, MedStar Washington Hospital Center, Washington, District of Columbia, USA, ${ }^{7}$ National Institute of Diabetes and Digestive and Kidney Diseases, National Institutes of Health, Bethesda, Maryland, USA, and ${ }^{8}$ Department of Neurological Surgery, Wexner Medical Center, The Ohio State University, Columbus, Ohio, USA

Correspondence should be addressed to P Chittiboina

Email prashant.chittiboina@nih.gov

\begin{abstract}
Context: Achievement of hypocortisolemia following transsphenoidal surgery (TSS) for Cushing's disease (CD) is associated with successful adenoma resection. However, up to one-third of these patients recur.

Objective: We assessed whether delay in reaching post-operative cortisol nadir may delineate patients at risk of recurrence for CD following TSS.

Methods: A retrospective review of 257 patients who received 291 TSS procedures for CD at NIH, between 2003 and 2016. Early biochemical remission (serum cortisol nadir $<5 \mu \mathrm{g} / \mathrm{dL}$ ) was confirmed with endocrinological and clinical follow-up. Recurrence was detected by laboratory testing, clinical stigmata or medication dependence during a median follow-up of 11 months.

Results: Of the 268 unique admissions, remission was recorded in 241 instances. Recurrence was observed in $9 \%$ of these cases with cortisol nadir $\leq 5 \mu \mathrm{g} / \mathrm{dL}$ and $6 \%$ of cases with cortisol nadir $\leq 2 \mu \mathrm{g} / \mathrm{dL}$. The timing of hypocortisolemia was critical in detecting late recurrences. Morning POD-1 cortisol $<3.3 \mu \mathrm{g} / \mathrm{dL}$ was $100 \%$ sensitive in predicting durable remission and morning POD-3 cortisol $\geq 18.5 \mu \mathrm{g} / \mathrm{dL}$ was $98.6 \%$ specific in predicting remote recurrence. AUROC analysis revealed that hypocortisolemia $\leq 5 \mu \mathrm{g} / \mathrm{dL}$ before $15 \mathrm{~h}$ (post-operative) had $95 \%$ sensitivity and an NPV of 0.98 for durable remission. Serum cortisol level $\leq 2 \mu \mathrm{g} / \mathrm{dL}$, when achieved before $21 \mathrm{~h}$, improved sensitivity to $100 \%$. Conclusions: In our cohort, early, profound hypocortisolemia could be used as a clinical prediction tool for durable remission. Achievement of hypocortisolemia $\leq 2 \mu \mathrm{g} / \mathrm{dL}$ before 21 post-operative hours appeared to accurately predict durable remission in the intermediate term.
\end{abstract}

\section{Introduction}

Left untreated, chronically elevated endogenous hypercortisolemia resulting from Cushing's disease (CD) is associated with significant morbidity and mortality $(1,2)$. Transsphenoidal surgery (TSS) for resection of

www.eje-online.org https://doi.org/10.1530/EJE-17-0873
(C) 2018 European Society of Endocrinology Printed in Great Britain
European Journal of Endocrinology (2018) 178, 255-263 
cortisol deficiency, due to suppression of the remaining normal pituitary corticotrophs by long-standing hypercortisolemia $(8,9)$. Given the short serum half-lives of ACTH and cortisol, a rapid drop in levels would be expected during the immediate post-operative period $(10,11)$. As demonstrated by the faster rate of decline in serum levels achieved by total hypophysectomy, when compared to subcapsular resection, there is evidence to suggest that the residual corticotrophs do remain functional following complete removal of the ACTH-secreting adenoma (12).

In the post-operative setting, failure to achieve hypocortisolemia is thought to reflect the presence of residual tumor cells $(13,14)$. Therefore, serum cortisol has become a well-established biochemical marker of early surgical remission, with rates reported to range from 65 to $98 \%$ at experienced centers $(15,16,17,18$, 19). However, despite early remission, recurrence has been observed in $2-35 \%$ of these cases, occurring up to thirty years post-operatively $(12,15,16,18,20,21,22)$. Because pituitary adenomas are monoclonal in origin, disease recurrence is thought to result from microscopic residual tumor corticotrophs left at the adenoma margin or unrecognized dural invasion along the wall of the cavernous sinus $(1,13,23,24)$. Early re-operation has been shown to achieve remission in the majority of these patients requiring further treatment $(13,15,25$, 26). This highlights the possibility that post-operative cortisol values may reflect the extent of microscopic resection.

In an attempt to define the subset of patients at high likelihood of recurrence, early identification of surgical success has been the focus of several recent studies $(17,19$, $20,21,27,28,29,30)$. The technique of pseudocapsular resection, hypothesized to achieve complete tumor resection, has been associated with a rapid rate of postoperative cortisol decline (12). More recently, normalized early post-operative values (NEPV), capitalizing on the potential for endoscopic TSS to act as an endogenous corticotrophin-releasing hormone (CRH) stimulation test, have been shown to improve accuracy in predicting early non-remission (30).

We hypothesized that the slope of serum cortisol decline in the immediate post-operative period may be used as a predictive biomarker for the completeness of tumor resection in ACTH-secreting pituitary adenoma. This may aid in the identification of patients who could benefit from enhanced biochemical follow-up to prevent disease relapse.

\section{Subjects and methods}

Data from 328 patients who received 364 consecutive sublabial transsphenoidal surgeries for adrenocorticotropic (ACTH)-secreting pituitary adenomas by a team of surgeons (EHO, RRL and PC) from December 2003 until July 2015 was retrospectively reviewed. All operations took place at the National Institutes of Health (NIH) Clinical Center in Bethesda, MD under research protocol NIH ID 03-N-0164 (clinicaltrials.gov identifier NCT00060541). Written informed consent was obtained from each patient for study participation, and the study was performed within the clinical and ethical guidelines of the Combined Neurosciences Institutional Review Board of the NIH.

\section{Diagnosis of Cushing's disease}

The work-up for CD has previously been described and is summarized below (31, 32, 33, 34, 35). Cushing's syndrome was confirmed on the basis of elevations of at least two of the following laboratory tests: late night salivary cortisol, 24-h urine free cortisol or low-dose dexamethasone suppression testing (1 mg overnight or $2 \mathrm{mg}$ over $48 \mathrm{~h}$, normal cortisol $<1.8 \mu \mathrm{g} / \mathrm{L})(1,35)$. Supplemental diagnostic testing included midnight serum cortisol and morning cortisol following $8 \mathrm{mg}$ overnight dexamethasone suppression testing (HDDST) $(36,37)$.

A diagnosis of $\mathrm{CD}$ was made in patients with ACTHdependent hypercortisolism with at least one of the following: response of serum cortisol or ACTH to ovine corticotropin-releasing hormone (oCRH) stimulation testing, identification of adenoma on magnetic resonance imaging (MRI) of the pituitary or a central-toperipheral ACTH gradient during inferior petrosal sinus sampling (IPSS) $(33,34,38)$. Pituitary microadenomas were detected as hypoattenuated regions within the sella on early, post gadolinium contrast 3D gradient recalled echo imaging $(39,40,41)$. IPSS was performed in patients where HDDST, oCRH and pre-operative MRI were not concordant (26).

The presence, size and location of lesions were recorded on the pre-operative MRI report. Surgical findings, denoting the size and location of the adenoma, were recorded on a graphical post-operative record of the pituitary gland. The presence and location of ACTHpositive pituitary adenoma on histopathology was noted. Concordance was referenced to imaging and/or surgical findings. 
The biochemical assays and imaging modalities used in this study have previously been described in the literature $(7,30,42)$.

\section{Post-operative outcomes}

Serum cortisol levels were routinely obtained at 6-h intervals from post-operative day 0 (POD-0) through day 3 (POD-3). The initial post-operative serum cortisol was obtained at 12:00 h POD-0 or 18:00 h depending upon the time of completion of surgery. After POD-3, daily morning cortisol levels were obtained until post-operative day 10 (POD-10) during their inpatient stay or until patient discharge $(27,30)$.

Early biochemical remission was assigned by detecting nadir serum cortisol level of $<5 \mu \mathrm{g} / \mathrm{dL}$ or $<2 \mu \mathrm{g} / \mathrm{dL}$ by POD10 , prior to administration of exogenous glucocorticoids and sustained hypocortisolemia necessitating glucocorticoid replacement (33). All patients in whom this was not achieved (persistent CD) were excluded from further analysis. For patients undergoing early repeat TSS for persistent $\mathrm{CD}$, cortisol values obtained after the final, successful TSS procedure were included for analysis.

Clinical stigmata of Cushing's syndrome (recurrence of height arrest in children, weight gain, hypertension, plethora), biochemical evidence of hypercortisolemia (24h urinary free cortisol, diurnal serum cortisol and ACTH or more recently, salivary cortisol), need medical therapy targeting Cushing's syndrome (ketoconazole initiation to suppress serum cortisol) or requirement for further surgical management formed the criteria for assigning recurrence.

\section{Statistical analysis}

Patients were divided into remission and recurrence groups for statistical analysis. Baseline clinical characteristics were presented as percentages or as means with standard deviations. Binomial variables were compared using two sample tests of proportions or two sample $T$-tests with unequal variance (43), while categorical variables were compared using chi-square and Fisher's exact tests, where appropriate. One-way ANOVA and Tukey post hoc tests were used for the comparison of proportions of means, reported as mean difference (MD). Kaplan-Meier analysis, using cortisol nadir as the survival event, was conducted to compare the time to reach post-operative cortisol nadir ( $\leq 5 \mu \mathrm{g} / \mathrm{dL}$ or $\leq 2 \mu \mathrm{g} / \mathrm{dL}$ ) between remission and recurrence groups. Statistical significance was assessed using the log-rank test (39). Additionally, CD recurrence was used as a survival event to distinguish the ability of cutoffs to predict durable remission. Predictors of recurrence were identified with logistic regression, using recurrence as the dependent variable and evaluated for quality of fit using areas under the receiver-operating characteristic curve (AUROC). Score cutoffs were chosen for sensitivity and specificity analysis after AUROC, confirmed using $2 \times 2$ tables. Standard errors were calculated by the DeLong method (40). $P$ values $<0.05$ two-tailed were considered statistically significant. GraphPad Prism 6.0 software was used for statistical figures (GraphPad Software). Statistical analyses were performed using SPSS, version 24.0 (IBM Corporation).

\section{Results}

Two hundred and fifty seven patients receiving 291 TSS procedures were included in this study. The rest were excluded due to lack of adequate post-operative laboratory values or due to inadequate follow-up. Twenty-three procedures were early repeat TSS surgeries for persistent CD; resulting in 268 unique admissions. Of these, remission was achieved in 241 (90\%) patients, with postoperative cortisol nadir $\leq 5 \mu \mathrm{g} / \mathrm{dL}$ within 10 post-operative days. Meanwhile, in 222 (82.8\%) hypocortisolemia of $\leq 2 \mu \mathrm{g} / \mathrm{dL}$ was detected within 10 post-operative days. Only the 241 instances with remission and hypocortisolemia $\leq 5 \mu \mathrm{g} / \mathrm{dL}$ were included for further analysis. Patients were followed up for a mean of 14 months (median 7 months, interquartile range 1-17 months, range 1-150 months).

\section{Recurrence}

At the last follow-up, recurrence was observed in $8.7 \%$ $(n=21 / 241)$ of cases achieving cortisol nadir $\leq 5 \mu \mathrm{g} / \mathrm{dL}$ and in $5.9 \%(n=13 / 222)$ of cases achieving cortisol nadir $\leq 2 \mu \mathrm{g} / \mathrm{dL}$. Of the 19 cases achieving cortisol nadir $\leq 5 \mu \mathrm{g} / \mathrm{dL}$ but not $\leq 2 \mu \mathrm{g} / \mathrm{dL}, 42 \% \quad(n=8)$ recurred. Recurrence occurred at a median of $11.86 \pm 20.52$ months. There was a statistically significant difference in the rate of recurrence between the three groups (ANOVA $F$ statistic $(2,479)=1551, P<0.001)$. Upon post hoc analysis, the difference remained significant $(P=(0.05 / 3)=0.0167$, for exploratory analysis) between each of the three nadir cutoff values of $\leq 5 \mu \mathrm{g} / \mathrm{dL}(\mathrm{A}), \leq 2 \mu \mathrm{g} / \mathrm{dL}$ (B) and $2.1-5 \mu \mathrm{g} / \mathrm{dL}$ (C) $(A$ vs $B \mathrm{MD}=0.03, P<0.001 ; A$ vs $C \mathrm{MD}=-0.33$, $P<0.001 ; B$ vs $C \mathrm{MD}=-0.36, P<0.001)$.

Patients did not differ significantly in BMI, gender, age or race between the durable remission 
and recurrence groups. As expected (41), the proportion of MRI-positive adenomas $(n=239)$; intraoperatively visualized macroscopic adenomas $(n=233$; pathology-confirmed adenomas $(n=232)$ and locationconcordance between imaging and histopathological findings $(n=239)$ did not differ significantly between the two groups. The rate of location-concordance between imaging and surgical findings $(n=153)$ was lower in the recurrence group (57 vs $42 \%, P=0.026$ ), suggesting that adenomas that were detected well both with imaging, during surgery tended to recur less frequently (Table 1$)$.

\section{Early post-operative serum cortisol analysis}

Survival analysis of time to reach nadir serum cortisol revealed a statistically significant difference between the durable remission and recurrence groups in patients achieving nadir serum cortisol $\leq 5 \mu \mathrm{g} / \mathrm{dL} \quad(P=0.002)$
(Fig. 1A). Despite a statistically significant difference observed on log-rank test, the median time to reach nadir cortisol $\leq 5 \mu \mathrm{g} / \mathrm{dL}$ was $42 \mathrm{~h}$ in both the remission and recurrence groups. No difference in time to reach nadir cortisol was found in patients within subgroups nadir $<2 \mu \mathrm{g} / \mathrm{dL}$ (Fig. 1B) or nadir 2-5 $\mu$ g/dL (Fig. 1C).

To assess the effect of immediate cortisol decline on rates of recurrence, we performed a subgroup analysis on patients with available early $(<42 \mathrm{~h})$ post-operative laboratory values $(n=128)$. This analysis enabled the exclusion of patients who had their first serum cortisol recorded at $\geq 42 \mathrm{~h}$ but who may have achieved nadir cortisol prior to his time. The median time to reach cortisol nadir $\leq 5 \mu \mathrm{g} / \mathrm{dL}$ was significantly different between the two groups (18h vs $42 \mathrm{~h} P=0.004$ ) (Fig. 1D and E). These findings suggest that patients who have eventual recurrence may have a slight delay in serum cortisol nadir following TSS. The findings also suggest that early serum cortisol $(<42 \mathrm{~h})$ is critical to detect this slight delay.

Table 1 Univariate logistic regression analysis identifying predictors of recurrence in patients achieving early biochemical remission. Remission was defined as cortisol nadir $\leq 5 \mu \mathrm{g} / \mathrm{mL}$ by POD-10. Measures of association are represented as odds ratio with corresponding $P$ values. Accounting for potential confounding variables of age, gender, BMI and ethnicity, adjusted odds ratio with corresponding $P$ values are presented.

\begin{tabular}{l} 
Variables \\
\hline Demographics \\
Age \\
BMI \\
Gender \\
White \\
Black \\
Asian \\
Perioperative outcomes \\
MRI positive \\
Visualized intra-operatively \\
Imaging/resection concordance \\
Pathology positive \\
Imaging/pathology concordance \\
Cortisol \\
00:00 h POD-0 \\
18:00 $\mathrm{h}$ POD-0 \\
00:00 h POD-1 \\
06:00 h POD-1 \\
12:00 h POD-1 \\
18:00 h POD-1 \\
18:00 h POD-2 \\
00:00 h POD-3 \\
$06: 00 \mathrm{~h}$ POD-3 \\
12:00 h POD-3 \\
18:00 $\mathrm{h}$ POD-3 \\
NEPV cortisol
\end{tabular}

\begin{tabular}{l}
\hline OR \\
\hline \\
\hline 1.023 \\
1.013 \\
0.737 \\
1.519 \\
0.585 \\
0.320 \\
\\
1.030 \\
0.664 \\
3.758 \\
1.958 \\
2.097 \\
\\
0.971 \\
0.974 \\
0.970 \\
0.933 \\
0.907 \\
0.889 \\
0.894 \\
1.023 \\
0.959 \\
0.900 \\
0.981 \\
0.931 \\
\hline
\end{tabular}

\begin{tabular}{|c|c|}
\hline $95 \% \mathrm{Cl}$ & S.E. \\
\hline $0.99,1.06$ & 0.016 \\
\hline $0.95,1.08$ & 0.031 \\
\hline $0.26,2.10$ & 0.534 \\
\hline $0.60,3.84$ & 0.474 \\
\hline $0.18,1.87$ & 0.594 \\
\hline $0.06,1.65$ & 0.837 \\
\hline $0.38,2.78$ & 0.506 \\
\hline $0.15,3.00$ & 0.770 \\
\hline $1.17,12.11$ & 0.597 \\
\hline $0.61,6.34$ & 0.600 \\
\hline $0.85,5.16$ & 0.460 \\
\hline $0.94,1.01$ & 0.018 \\
\hline $0.94,1.01$ & 0.017 \\
\hline $0.94,1.01$ & 0.017 \\
\hline $0.89,0.98$ & 0.026 \\
\hline $0.82,1.00$ & 0.049 \\
\hline $0.81,0.98$ & 0.048 \\
\hline $0.78,1.03$ & 0.072 \\
\hline 0.891 .18 & 0.073 \\
\hline $0.92,1.00$ & 0.022 \\
\hline $0.82,1.00$ & 0.050 * \\
\hline $0.93,1.04$ & 0.028 \\
\hline $0.87,0.99$ & $0.033^{*}$ \\
\hline
\end{tabular}

\begin{tabular}{|c|c|c|}
\hline$P$ Value & Adj OR & $P$ Value \\
\hline \multicolumn{3}{|l|}{0.150} \\
\hline \multicolumn{3}{|l|}{0.663} \\
\hline \multicolumn{3}{|l|}{0.568} \\
\hline \multicolumn{3}{|l|}{0.378} \\
\hline \multicolumn{3}{|l|}{0.366} \\
\hline \multicolumn{3}{|l|}{0.173} \\
\hline 0.954 & 0.877 & 0.812 \\
\hline 0.595 & 0.683 & 0.637 \\
\hline $0.027 *$ & 7.010 & $0.006 * *$ \\
\hline 0.262 & 2.196 & 0.238 \\
\hline 0.107 & 1.039 & 0.074 \\
\hline 0.109 & 0.962 & 0.068 \\
\hline 0.116 & 0.970 & 0.135 \\
\hline 0.075 & 0.959 & 0.061 \\
\hline $0.007 * *$ & 0.904 & $0.002 * *$ \\
\hline $0.043 *$ & 0.873 & $0.040 *$ \\
\hline $0.014 *$ & 0.887 & $0.028 *$ \\
\hline 0.119 & 0.847 & 0.072 \\
\hline 0.752 & 1.030 & 0.748 \\
\hline 0.062 & 0.959 & 0.062 \\
\hline 0.036 * & 0.882 & 0.130 \\
\hline 0.487 & 1.010 & 0.842 \\
\hline $0.031 *$ & 0.902 & $0.039 *$ \\
\hline
\end{tabular}

Those of statistical significance are marked with asterisks

Adj, adjusted; BMI, body mass index; OR, odds ratio; POD, post-operative day; s.E., standard error; $P$ value, probability value. 
A

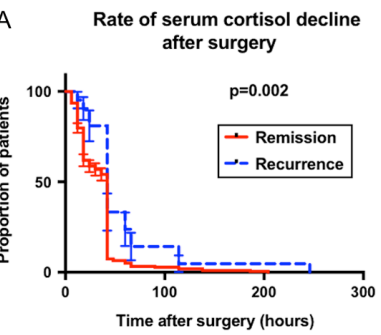

C Rate of serum cortisol decline

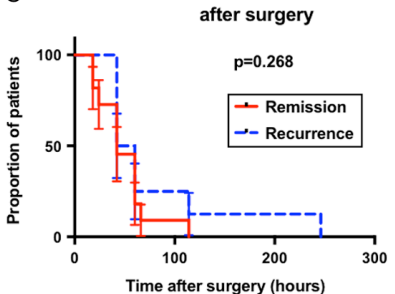

E Rate of serum cortisol decline

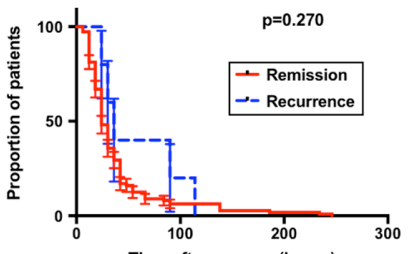

Time after surgery (hours)
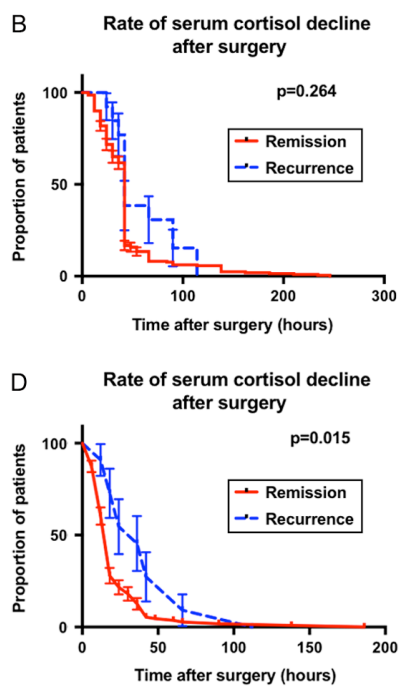

\section{Figure 1}

Graphs showing the results of the Kaplan-Meier analysis comparing remission and recurrence groups. (A) Comparison in all patients achieving cortisol nadir $5 \mu \mathrm{g} / \mathrm{dL}$ by POD- 10 .

(B) Comparison of in all patients achieving cortisol nadir $2 \mu \mathrm{g} / \mathrm{dL}$ by POD-10. (C) Comparison in patients achieving cortisol nadir $2.1-5 \mu \mathrm{g} / \mathrm{dL}$ by POD-10. (D) Comparison in patients who had the initial serum cortisol drawn within the first 42 post-operative hours and who achieved cortisol nadir $5 \mu \mathrm{g} / \mathrm{dL}$ by POD-10. (E) Comparison in patients who had the initial serum cortisol drawn within the first 42 post-operative hours and who achieved cortisol nadir $2 \mu \mathrm{g} / \mathrm{dL}$ by POD-10. POD, post-operative day.

\section{Biochemical predictors of recurrence}

To identify predictors of recurrence, we performed logistic regression analysis after adjusting for age, BMI, gender and ethnicity. Morning (06:00h) POD-1 $(P=0.002)$, noon (12:00h) POD-1 $(P=0.040)$ and evening (18:00h) POD-1 $(P=0.028)$ cortisol were significantly associated with recurrence (Table 1). Normalized early post-operative values, accurate predictors of early non-remission (30), were analyzed for their potential to predict longterm recurrence. Logistic regression analysis revealed a significant difference between the durable remission and recurrence groups $(P=0.026)$ (Table 1$)$.

Table 2 Comparison of post-operative serum cortisol in patients achieving early remission by POD-10. Results of AUROC analyses with recurrence as the reference variable. Remission was defined as cortisol nadir $\leq 5 \mu \mathrm{g} / \mathrm{dL}$. Recurrence was defined by biochemical hormone levels, clinical stigmata or medication requirement.

\begin{tabular}{|c|c|c|c|c|c|}
\hline Cortisol & AUROC & $95 \% \mathrm{Cl}$ & S.D. & $n$ & $P$ Value \\
\hline \multicolumn{6}{|l|}{ POD-1 } \\
\hline $00: 00 \mathrm{~h}$ & 0.775 & $0.64,0.91$ & 0.067 & 94 & $0.010 * *$ \\
\hline 06:00h & 0.839 & $0.74,0.94$ & 0.052 & 119 & $<0.001 * * *$ \\
\hline $12: 00 \mathrm{~h}$ & 0.761 & $0.63,0.89$ & 0.068 & 103 & $0.015^{*}$ \\
\hline $18: 00 \mathrm{~h}$ & 0.724 & $0.52,0.93$ & 0.105 & 98 & $0.039 *$ \\
\hline \multicolumn{6}{|l|}{ POD-3 } \\
\hline $06: 00 \mathrm{~h}$ & 0.742 & $0.63,0.85$ & 0.056 & 228 & $<0.001 * * *$ \\
\hline $12: 00 \mathrm{~h}$ & 0.753 & $0.53,0.97$ & 0.111 & 52 & $0.044 *$ \\
\hline $18: 00 \mathrm{~h}$ & 0.897 & $0.77,1.03$ & 0.055 & 42 & $0.023^{*}$ \\
\hline NEPV & 0.832 & $0.72,0.94$ & 0.055 & 65 & $0.007 * *$ \\
\hline \multicolumn{6}{|l|}{ Nadir } \\
\hline$\leq 5 \mu \mathrm{g} / \mathrm{dL}$ & 0.714 & $0.60,0.83$ & 0.058 & 241 & $0.001 * * *$ \\
\hline$\leq 2 \mu \mathrm{g} / \mathrm{dL}$ & 0.661 & $0.51,0.80$ & 0.073 & 222 & 0.050 * \\
\hline
\end{tabular}

AUROC, area under the receiver-operating curve; $\mathrm{Cl}$, confidence interval; NEPV, normalized early post-operative value; $P O D$, post-operative day; $P$ value, probability value; ${ }^{*} P<0.05 ;{ }^{*} P<0.01 ; * * * P<0.001$.

Area under the receiver-operating characteristic curve (AUROC) was used to assess the accuracy of association between post-operative cortisol levels and recurrence. Serum cortisol at 06:00h POD-1 and 18:00h POD-3 yielded the highest ROC $0.84, P<0.001 ; 0.90, P<0.023$, respectively. NEPV and serum cortisol levels throughout POD-1 and POD-3 remained significant predictors of recurrence (Table 2). Sensitivity and specificity analysis identified a cutoff of $<3.3 \mu \mathrm{g} / \mathrm{dL}$ for serum cortisol at 06:00h POD-1. This achieved a sensitivity of 100\%, specificity of 59\% and NPV of 1.0 in predicting durable remission. Applying the cutoff of $<3.3 \mu \mathrm{g} / \mathrm{dL}$ to $06: 00 \mathrm{~h}$ POD-1, revealed a significant difference in recurrence rates. There were no observed recurrences in patients whose serum cortisol values reached $<3.3 \mu \mathrm{g} / \mathrm{dL}$ by 06:00 on POD1 $(n=55)$. Patients with values above $3.3 \mu \mathrm{g} / \mathrm{dL}$ $(n=64)$ recurred on an average of 12 months after TSS $(P=0.02)$ (Fig. 2). Furthermore, a cutoff of $>18.5 \mu \mathrm{g} / \mathrm{dL}$ for serum cortisol at 06:00 h POD-3 achieved a specificity of 98.6\%, sensitivity of $14 \%$ and PPV of 0.92 in predicting recurrence (despite nadir $\leq 5 \mu \mathrm{g} / \mathrm{dL}$ at other time points).

Further AUROC analyses performed to assess accuracy of association between time to reach post-operative cortisol nadir $\leq 5 \mu \mathrm{g} / \mathrm{dL}$ and remission yielded a ROC of $0.71, P=0.001$ (Table 2 ). Applying a cutoff of $15 \mathrm{~h}$ to reach cortisol nadir $\leq 5 \mu \mathrm{g} / \mathrm{dL}$ achieved a sensitivity of $95 \%$, specificity of 21\% NPV 0.98 and PPV 0.10 in predicting durable remission. Association between time to reach 


\section{Comparison of remission rates in patients above and below the cutoff 6am POD-1 cortisol}

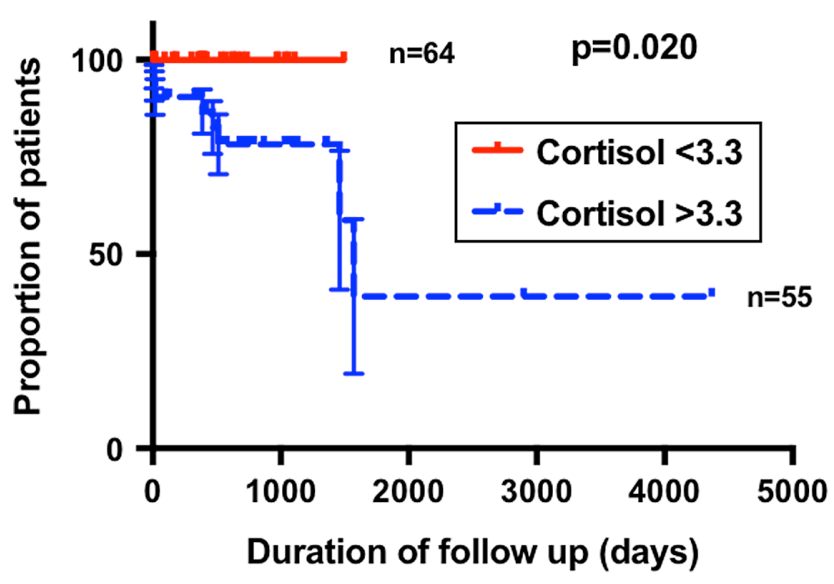

\section{Figure 2}

Kaplan-Meier analysis comparing recurrence rates in patients above and below the cortisol cutoffs of 06:00 h POD- $1<3.3 \mu \mathrm{g} /$ dL. POD, post-operative day.

post-operative cortisol nadir $\leq 2 \mu \mathrm{g} / \mathrm{dL}$ and durable remission yielded a ROC of $0.66, P=0.05$ (Table 2). Applying a cutoff of $21 \mathrm{~h}$ to reach cortisol nadir $\leq 2 \mu \mathrm{g} / \mathrm{dL}$ achieved a sensitivity of $100 \%$, specificity of $18 \%$ NPV 1.0 and PPV 0.7 in predicting durable remission. These results suggest that early, profound hypocortisolemia following TSS may predict durability of remission from CD.

\section{Discussion}

Identifying predictors of recurrence after resection of ACTH-secreting pituitary adenomas presents a significant clinical challenge. Transsphenoidal surgery, which has the ability to provide rapid symptom relief, effectively moderates the risk of permanent organ damage resulting from hormonal excess $(1,6,29)$. Post-operative biochemical markers, therefore, define immediate surgical outcomes $(4,6,9,10,22,25,27,33,38,43,44,45)$. The reported remission rates vary widely, ranging from 65 to $97 \%$ and may depend on surgical expertise and case volume $(2,3,4,5,6,7,12,14,15,16,17,18,19,20,21$, $22,23,24,25,26,27)$. In recent times, the need for clear criteria defining early biochemical remission has been recognized, in order to better standardize treatment effects in this patient group $(5,46)$. Furthermore, in a subset of patients who do achieve early post-operative biochemical remission, subsequent recurrence of hypercortisolemia on long-term follow-up has been documented $(4,5,6,12,15$, $16,18,19,20,21,29,47)$.

In our retrospective review of 291 patients treated at a single center, $87 \%$ and $79 \%$ of patients achieved early hypocortisolemia, $\leq 5 \mu \mathrm{g} / \mathrm{dL}$ and $\leq 2 \mu \mathrm{g} / \mathrm{dL}$, respectively. Lindsay and coworkers, in a review of 331 patients, have previously reported concordant rates of hypocortisolemia at $98 \%$ and $87 \%$ for serum cortisol $\leq 5 \mu \mathrm{g} / \mathrm{dL}$ and $\leq 2 \mu \mathrm{g} / \mathrm{dL}$, respectively (27). However, while their group found no significant difference in recurrence rates between the respective nadir cortisol levels, we were able to demonstrate a significantly higher recurrence rate in patients who did not achieve cortisol nadir $<2 \mu \mathrm{g} / \mathrm{dL}$. We suspect that we were able to detect a difference due to the availability of early $(<42 \mathrm{~h})$ post-operative serum cortisol values. As hypothesized by Monteith and coworkers, this finding suggests that the rate of cortisol decline, and nadir cortisol level, may be associated with completeness of adenoma resection and thereby predict long-term outcomes in patients with CD (12). This hypothesis is also supported by occurrence of same-site recurrence in patients with prior remission from CD (48).

Post-operative hypocortisolemia following ACTHsecreting adenoma resection is thought to be due to chronic suppression of non-adenomatous pituitary corticotrophs in the setting of endogeonous hypercortisolemia $(9,49$, 50). However, observed differences in serum cortisol and ACTH levels following total hypophysectomy vs adenomectomy suggest some preserved corticotroph secretory function in the normal gland (12). This preserved response was utilized by Asuzu and coworkers to detect a stress-response induced in the immediate post-operative period $(30,51)$. Therefore, identification of optimal time points for recording serum cortisol is necessary to differentiate the contributions of normal gland and residual tumor. We found that normalized early postoperative cortisol, an effective marker of early remission (30), did not significantly predict long-term recurrence in our patient cohort. Therefore, same-day post-operative serum cortisol values may not be useful for the prediction of eventual recurrence.

We then analyzed post-operative serum cortisol levels to formulate a predictive model for risk of recurrence based on the magnitude and slope of hypocortisolemia. Achievement of nadir cortisol $<2 \mu \mathrm{g} / \mathrm{dL}$ or $<5 \mu \mathrm{g} /$ $\mathrm{dL}$ between $12 \mathrm{~h}$ and five days post-operatively has previously been well documented to be a reliable marker of early remission $(25,31,52,53)$. However, profound post-operative hypocortisolemia has been reported to 
have very poor accuracy in predicting durable remission $(27,54,55,56)$. In our cohort, however, 06:00-h POD-1 cortisol $<3.3 \mu \mathrm{g} / \mathrm{dL}$ was able to predict durable remission with a sensitivity of 100\%. Additionally, 06:00-h POD-3 cortisol $>18.6 \mu \mathrm{g} / \mathrm{dL}$ demonstrated $99 \%$ specificity as a predictor of recurrence. Prior studies that tested the predictive ability of profound hypocortisolemia or undetectable serum cortisols had serum cortisols drawn more than 3 post-operative days $(27,54,55,56)$. We found that unlike Lindsay and coworkers who obtained cortisol levels on post-operative days 3-5 (27), many patients $(n=127)$ in the current cohort had earlier (starting approximately 3-6h post-operatively) laboratory values available. We suspected that the slope of cortisol decline in the post-operative period is critical to determining the likelihood of the presence of microscopic residual tumor remnant. Therefore, we believe that inclusion of early post-operative $(<42 \mathrm{~h})$ serum cortisols were critical to improve the predictive accuracy for durable remission. In patients with available early serum cortisol values, and eventual durable remission, hypocortisolemia $\leq 5 \mu \mathrm{g} / \mathrm{dL}$ was achieved within $15 \mathrm{~h}$ (Fig. 1D).

Based on the findings from descriptive analyses, we performed AUROC analyses to generate clinically useful predictive tools. In our model, we assessed whether the slope of fall in serum cortisol could predict durable remission. In our model, hypocortisolemia $\leq 5 \mu \mathrm{g} / \mathrm{dL}$ by $15 \mathrm{~h}$ had $97 \%$ sensitivity and an NPV of 0.98 for durable remission. Similarly, in our model, a lower serum cortisol level of $\leq 2 \mu \mathrm{g} / \mathrm{dL}$ could be achieved by a later time-point of $21 \mathrm{~h}$ to improve the sensitivity to $100 \%$ and NPV to 1.0. Our findings suggest that early post-operative serum cortisol testing may have a role in predicting long-term outcomes following TSS for CD.

Although the data in this study was drawn from a large cohort of patients with CD, its quality is limited by the retrospective study design. Cortisol laboratory values in the first 42 post-operative hours were missing from a number of patients, who were excluded from further analysis. Semi-autonomous cortisol production due to adrenal nodule formation can severely inhibit correct application of these findings (57). Furthermore, our mean 11-month follow-up period is unlikely to reflect the biochemical characteristics of all patients who experienced long-term recurrence, known to occur up to decades postoperatively. A median time to recurrence of 12 months in the subset of patients with 06:00-h POD-1 cortisol $>3.3 \mu \mathrm{g} /$ $\mathrm{dL}$, highlights this. While surgical technique, surgeon expertise and volume of cases can affect outcomes (1), all included patients underwent surgery at a single center.

\section{Conclusions}

In our cohort of patients with $\mathrm{CD}$, the slope in serum cortisol decline in the immediate post-operative period acted as a biochemical marker of recurrence. We found that achievement of hypocortisolemia $\leq 5 \mu \mathrm{g} / \mathrm{dL}$ by $15 \mathrm{~h}$ or $\leq 2 \mu \mathrm{g} / \mathrm{dL}$ by $21 \mathrm{~h}$ appeared to be an accurate predictor of durable remission in the intermediate term. Such a clinical prediction tool may have significant utility in the management of $\mathrm{CD}$. Further validation of its accuracy in a multi-center prospective study with longer-term follow-up is, warranted.

\section{Declaration of interest}

The authors declare that there is no conflict of interest that could be perceived as prejudicing the impartiality of this study.

\section{Funding}

This work was supported by National Institutes of Health Intramural Grant ZIA NS003150-01 awarded to Prashant Chittiboina. This work was supported by the Intramural Research Programs of the National Institute of Neurological Diseases and Stroke, and Eunice Kennedy Shriver National Institute for Child Health and Human Development, Bethesda, MD.

\section{Author contribution statement}

Data collection: S B, M L, S S, L N, C A S, R R, P C; data analysis: N I, G C, D A, P C; manuscript drafting: N I, G C, P C; critical review of manuscript: all authors; study supervision: P C.

\section{Acknowledgements}

The authors express gratitude to and recognize the foundational insights for this work from Dr Edward $\mathrm{H}$ Oldfield. Dr Oldfield expired earlier this year and was not able to critically review the final version of this manuscript.

\section{References}

1 Lonser RR, Nieman L \& Oldfield EH. Cushing's disease: pathobiology, diagnosis, and management. Journal of Neurosurgery $2017 \mathbf{1 2 6}$ 404-417. (https://doi.org/10.3171/2016.1.JNS152119)

2 Clayton RN, Raskauskiene D, Reulen RC \& Jones PW. Mortality and morbidity in Cushing's disease over 50 years in Stoke-on-Trent, UK: audit and meta-analysis of literature. Journal of Clinical Endocrinology and Metabolism 201196 632-642. (https://doi.org/10.1210/jc.20101942)

3 Rees DA, Hanna FWF, Davies JS, Mills RG, Vafidis J \& Scanlon MF. Long-term follow-up results of transsphenoidal surgery for Cushing's disease in a single centre using strict criteria for remission. Clinical Endocrinology 200256 541-551. (https://doi.org/10.1046/j.13652265.2002.01511.x)

4 Roelfsema F, Biermasz NR \& Pereira AM. Clinical factors involved in the recurrence of pituitary adenomas after surgical remission: a structured review and meta-analysis. Pituitary 201215 71-83. (https://doi.org/10.1007/s11102-011-0347-7)

5 Czepielewski MA, Rollin GAFS, Casagrande A \& Ferreira NP. Criteria of cure and remission in Cushing's disease: an update. Arquivos 
Brasileiros de Endocrinologia and Metabologia 200751 1362-1372. (https://doi.org/10.1590/S0004-27302007000800023)

6 Hammer GD, Tyrrell JB, Lamborn KR, Applebury CB, Hannegan ET, Bell S, Rahl R, Lu A \& Wilson CB. Transsphenoidal microsurgery for Cushing's disease: initial outcome and long-term results. Journal of Clinical Endocrinology and Metabolism 200489 6348-6357. (https:// doi.org/10.1210/jc.2003-032180)

7 Lonser RR, Wind JJ, Nieman LK, Weil RJ, DeVroom HL \& Oldfield EH. Outcome of surgical treatment of 200 children with Cushing's disease. Journal of Clinical Endocrinology and Metabolism 201398 892-901. (https://doi.org/10.1210/jc.2012-3604)

8 Grino M, Boudouresque F, Conte-Devolx B, Gunz G, Grisoli F, Oliver C \& Jaquet P. In vitro corticotropin-releasing hormone (CRH) stimulation of adrenocorticotropin release from corticotroph adenoma cells: effect of prolonged exposure to CRH and its interaction with cortisol. Journal of Clinical Endocrinology and Metabolism 198866 770-775. (https://doi.org/10.1210/jcem-66-4-770)

9 Hauger RL, Millan MA, Catt KJ \& Aguilera G. Differential regulation of brain and pituitary corticotropin-releasing factor receptors by corticosterone. Endocrinology 1987120 1527-1533. (https://doi. org/10.1210/endo-120-4-1527)

10 Veldhuis JD, Iranmanesh A, Johnson ML \& Lizarralde G. Twentyfour-hour rhythms in plasma concentrations of adenohypophyseal hormones are generated by distinct amplitude and/or frequency modulation of underlying pituitary secretory bursts. Journal of Clinical Endocrinology and Metabolism 199071 1616-1623. (https:// doi.org/10.1210/jcem-71-6-1616)

11 Iranmanesh A, Lizarralde G, Short D \& Veldhuis JD. Intensive venous sampling paradigms disclose high frequency adrenocorticotropin release episodes in normal men. Journal of Clinical Endocrinology and Metabolism 199071 1276-1283. (https://doi.org/10.1210/jcem-71-5-1276)

12 Monteith SJ, Starke RM, Jane JA \& Oldfield EH. Use of the histological pseudocapsule in surgery for Cushing disease: rapid postoperative cortisol decline predicting complete tumor resection. Journal of Neurosurgery 2012116 721-727. (https://doi. org/10.3171/2011.12.JNS11886)

13 Dickerman RD \& Oldfield EH. Basis of persistent and recurrent Cushing disease: an analysis of findings at repeated pituitary surgery. Journal of Neurosurgery 200297 1343-1349. (https://doi.org/10.3171/ jns.2002.97.6.1343)

14 Trainer PJ, Lawrie HS, Verhelst J, Howlett TA, Lowe DG, Grossman AB, Savage MO, Afshar F \& Besser GM. Transsphenoidal resection in Cushing's disease: undetectable serum cortisol as the definition of successful treatment. Clinical Endocrinology 199338 73-78. (https://doi.org/10.1111/j.1365-2265.1993.tb00975.x)

15 Dimopoulou C, Schopohl J, Rachinger W, Buchfelder M, Honegger J, Reincke M \& Stalla GK. Long-term remission and recurrence rates after first and second transsphenoidal surgery for Cushing's disease: care reality in the Munich metropolitan region. European Journal of Endocrinology 2014170 283-292. (https://doi.org/10.1530/EJE-13-0634)

16 Dallapiazza RF, Oldfield EH \& Jane JA. Surgical management of Cushing's disease. Pituitary 201518 211-216. (https://doi. org/10.1007/s11102-015-0646-5)

17 Costenaro F, Rodrigues TC, Rollin GAF, Ferreira NP \& Czepielewski MA. Evaluation of Cushing's disease remission after transsphenoidal surgery based on early serum cortisol dynamics. Clinical Endocrinology 201480 411-418. (https://doi.org/10.1111/ cen.12300)

18 Aranda G, Enseñat J, Mora M, Puig-Domingo M, Martínez de Osaba MJ, Casals G, Verger E, Ribalta MT, Hanzu FA \& Halperin I. Long-term remission and recurrence rate in a cohort of Cushing's disease: the need for long-term follow-up. Pituitary 201518 142-149. (https://doi.org/10.1007/s11102-014-0567-8)

19 Alexandraki KI, Kaltsas GA, Isidori AM, Storr HL, Afshar F, Sabin I, Akker SA, Chew SL, Drake WM, Monson JP et al. Long-term remission and recurrence rates in Cushing's disease: predictive factors in a single-centre study. European Journal of Endocrinology 2013168 639-648. (https://doi.org/10.1530/EJE-12-0921)

20 Ramm-Pettersen J, Halvorsen H, Evang JA, Rønning P, Hol PK, Bollerslev J, Berg-Johnsen J \& Helseth E. Low immediate postoperative serum-cortisol nadir predicts the short-term, but not long-term, remission after pituitary surgery for Cushing's disease. BMC Endocrine Disorders 201515 62. (https://doi.org/10.1186/ s12902-015-0055-9)

21 Hameed N, Yedinak CG, Brzana J, Gultekin SH, Coppa ND, Dogan A, Delashaw JB \& Fleseriu M. Remission rate after transsphenoidal surgery in patients with pathologically confirmed Cushing's disease, the role of cortisol, ACTH assessment and immediate reoperation: a large single center experience. Pituitary 201316 452-458. (https:// doi.org/10.1007/s11102-012-0455-z)

22 Nakane T, Kuwayama A, Watanabe M, Takahashi T, Kato T, Ichihara K \& Kageyama N. Long term results of transsphenoidal adenomectomy in patients with Cushing's disease. Neurosurgery 198721 218-222. (https://doi.org/10.1227/00006123-198708000-00015)

23 Trousseau H \& Endocriniennes M. Monoclonality of corticotroph Cushing's disease. Journal of Clinical Endocrinology and Metabolism 1992 472-475.

24 Schulte HM, Oldfield EH, Allolio B, Katz DA, Berkman RA \& Ali IU. Clonal composition of pituitary adenomas in patients with Cushing's disease: determination by X-chromosome inactivation analysis. Journal of Clinical Endocrinology and Metabolism 199173 1302-1308. (https://doi.org/10.1210/jcem-73-6-1302)

25 Friedman RB, Oldfield EH, Nieman LK, Chrousos GP, Doppman JL, Cutler GB \& Loriaux DL. Repeat transsphenoidal surgery for Cushing's disease. Journal of Neurosurgery 198971 520-527. (https:// doi.org/10.3171/jns.1989.71.4.0520)

26 Oldfield EH, Doppman JL, Nieman LK, Chrousos GP, Miller DL, Katz DA, Cutler GB \& Loriaux DL. Petrosal sinus sampling with and without corticotropin-releasing hormone for the differential diagnosis of Cushing's syndrome. New England Journal of Medicine 1991325 897-905. (https://doi.org/10.1056/ NEJM199109263251301)

27 Lindsay JR, Oldfield EH, Stratakis CA \& Nieman LK. The postoperative basal cortisol and CRH tests for prediction of long-term remission from Cushing's disease after transsphenoidal surgery. Journal of Clinical Endocrinology and Metabolism 201196 2057-2064. (https://doi.org/10.1210/jc.2011-0456)

28 Abu Dabrh AMA, Singh Ospina NM, Al Nofal A, Farah WH, Barrionuevo P, Sarigianni M, Mohabbat AB, Benkhadra K, Carranza Leon BG, Gionfriddo MR et al. Predictors of biochemical remission and recurrence after surgical and radiation treatments of Cushing disease: a systematic review and meta-analysis. Endocrine Practice 201622 466-475. (https://doi.org/10.4158/EP15922.RA)

29 Lambert JK, Goldberg L, Fayngold S, Kostadinov J, Post KD \& Geer EB. Predictors of mortality and long-term outcomes in treated Cushing's disease: a study of 346 patients. Journal of Clinical Endocrinology and Metabolism 201398 1022-1030. (https://doi. org/10.1210/jc.2012-2893)

30 Asuzu D, Chatain GP, Hayes C, Benzo S, McGlotten R, Keil M, Beri A, Sharma ST, Nieman L, Lodish M et al. Normalized early post-operative cortisol and ACTH values predict nonremission after surgery for Cushing's disease. Journal of Clinical Endocrinology and Metabolism 2017102 2179-2187. (https://doi.org/10.1210/jc.2016-3908)

31 Papanicolaou DA, Yanovski JA, Cutler GB, Chrousos GP \& Nieman LK. A single midnight serum cortisol measurement distinguishes Cushing's syndrome from pseudo-Cushing states. Journal of Clinical Endocrinology and Metabolism 199883 1163-1167. (https://doi.org/10.1210/jcem.83.4.4733)

32 Newell-Price J, Trainer P, Perry L, Wass J, Grossman A \& Besser M. A single sleeping midnight cortisol has $100 \%$ sensitivity for the diagnosis of Cushing's syndrome. Clinical Endocrinology 199543 545-550. (https://doi.org/10.1111/j.1365-2265.1995.tb02918.x) 
33 Dichek HL, Nieman LK, Oldfield EH, Pass HI, Malley JD \& Cutler GB. A comparison of the standard high dose dexamethasone suppression test and the overnight 8-mg dexamethasone suppression test for the differential diagnosis of adrenocorticotropin-dependent Cushing's syndrome. Journal of Clinical Endocrinology and Metabolism $1994 \mathbf{7 8}$ 418-422. (https://doi.org/10.1210/jcem.78.2.8106630)

34 Nieman LK, Oldfield EH, Wesley R, Chrousos GP, Loriaux DL \& Cutler GB. A simplified morning ovine corticotropin-releasing hormone stimulation test for the differential diagnosis of adrenocorticotropin-dependent Cushing's syndrome. Journal of Clinical Endocrinology and Metabolism 199377 1308-1312. (https:// doi.org/10.1210/jcem.77.5.8077325)

35 Guignat L \& Bertherat J. The diagnosis of Cushing's syndrome: an Endocrine Society Clinical Practice Guideline: commentary from a European perspective. European Journal of Endocrinology 2010163 9-13. (https://doi.org/10.1530/EJE-09-0627)

36 Hsiao HP, Kirschner LS, Bourdeau I, Keil MF, Boikos SA, Verma S, Robinson-White AJ, Nesterova M, Lacroix A \& Stratakis CA. Clinical and genetic heterogeneity, overlap with other tumor syndromes, and atypical glucocorticoid hormone secretion in adrenocorticotropinindependent macronodular adrenal hyperplasia compared with other adrenocortical tumors. Journal of Clinical Endocrinology and Metabolism 200994 2930-2937. (https://doi.org/10.1210/jc.2009-0516)

37 Nieman LK, Biller BMK, Findling JW, Newell-Price J, Savage MO, Stewart PM, Montori VM \& Edwards H. The diagnosis of Cushing's syndrome: an endocrine society clinical practice guideline. Journal of Clinical Endocrinology and Metabolism 200893 1526-1540. (https:// doi.org/10.1210/jc.2008-0125)

38 Günes M, Celik O \& Kadioglu P. Reliability of the diagnostic tests for Cushing's syndrome performed in a tertiary referral center. Pituitary 201316 139-145. (https://doi.org/10.1007/s11102-012-0387-7)

39 Dwyer AJ, Frank JA, Doppman JL, Oldfield EH, Hickey AM, Cutler GB, Loriaux DL \& Schiable TF. Pituitary adenomas in patients with Cushing disease: initial experience with Gd-DTPA-enhanced MR imaging. Radiology 1987163 421-426. (https://doi.org/10.1148/ radiology.163.2.3562821)

40 Doppman JL, Frank JA, Dwyer AJ, Oldfield EH, Miller DL, Nieman LK, Chrousos GP, Cutler GB \& Loriaux DL. Gadolinium DTPA enhanced MR imaging of ACTH-secreting microadenomas of the pituitary gland. Journal of Computer Assisted Tomography 198812 728-735. (https://doi.org/10.1097/00004728-198809010-00002)

41 Patronas N, Bulakbasi N, Stratakis CA, Lafferty A, Oldfield EH, Doppman J \& Nieman LK. Spoiled gradient recalled acquisition in the steady state technique is superior to conventional postcontrast spin echo technique for magnetic resonance imaging detection of adrenocorticotropin-secreting pituitary tumors. Journal of Clinical Endocrinology and Metabolism 200388 1565-1569. (https://doi. org/10.1210/jc.2002-021438)

42 Patronas N, Bulakbasi N, Stratakis CA, Lafferty A, Oldfield EH, Doppman J, Nieman LK, Grant W, Clinical M, Branch DE et al. Spoiled gradient recalled acquisition in the steady state technique is superior to conventional postcontrast spin echo technique for magnetic resonance imaging detection of adrenocorticotropin-secreting pituitary tumors. Journal of Clinical Endocrinology and Metabolism 2003 88 1565-1569. (https://doi.org/10.1210/jc.2002-021438)

43 Welch BL. The generalisation of student's problems when several different population variances are involved. Biometrika 194734 28-35.

44 Meij BP, Lopes MBS, Ellegala DB, Alden TD \& Laws ER. The longterm significance of microscopic dural invasion in 354 patients with pituitary adenomas treated with transsphenoidal surgery.
Journal of Neurosurgery 200296 195-208. (https://doi.org/10.3171/ jns.2002.96.2.0195)

45 Hassan-Smith ZK, Sherlock M, Reulen RC, Arlt W, Ayuk J, Toogood AA, Cooper MS, Johnson AP, \& Stewart PM. Outcome of Cushing's disease following transsphenoidal surgery in a single center over 20 years. Journal of Clinical Endocrinology and Metabolism 201297 1194-1201. (https://doi.org/10.1210/jc.2011-2957)

46 Rutkowski MJ, Breshears JD, Kunwar S, Aghi MK \& Blevins LS. Approach to the postoperative patient with Cushing's disease. Pituitary 201518 232-237. (https://doi.org/10.1007/s11102-015-0644-7)

47 Alwani RA, de Herder WW, van Aken MO, van den Berge JH, Delwel EJ, Dallenga AHG, De Jong FH, Lamberts SWJ, van der Lely AJ, \& Feelders RA. Biochemical predictors of outcome of pituitary surgery for Cushing's disease. Neuroendocrinology 201091 169-178. (https://doi.org/10.1159/000258677)

48 Dickerman RD \& Oldfield EH. Basis of persistent and recurrent Cushing disease: an analysis of findings at repeated pituitary surgery. Journal of Neurosurgery 200297 1343-1349. (https://doi.org/10.3171/ jns.2002.97.6.1343)

49 Ochedalski T, Rabadan-Diehl C \& Aguilera G. Interaction between glucocorticoids and corticotropin releasing hormone (CRH) in the regulation of the pituitary CRH receptor in vivo in the rat. Journal of Neuroendocrinology 199810 363-369. (https://doi.org/10.1046/j.13652826.1998.00212.x)

50 Anderson SM, Kant GJ \& Souza EB De. Effects of chronic stress on anterior pituitary and brain corticotropin-releasing factor receptors. Pharmacology, Biochemistry, and Behavior 199344 755-761. (https:// doi.org/10.1016/0091-3057(93)90002-B)

51 Udelsman R, Norton JA, Jelenich SE, Goldstein DS, Linehan WM, Loriaux DL \& Chrousos GP. Responses of the hypothalamicpituitary-adrenal and renin-angiotensin axes and the sympathetic system during controlled surgical and anesthetic stress. Journal of Clinical Endocrinology and Metabolism 198764 986-994. (https://doi. org/10.1210/jcem-64-5-986)

52 Ram Z, Nieman LK, Cutler GB, Chrousos GP, Doppman JL \& Oldfield EH. Early repeat surgery for persistent Cushing's disease. Journal of Neurosurgery 199480 37-45. (https://doi.org/10.3171/ jns.1994.80.1.0037)

53 Salassa RM, Laws ER, Carpenter PC \& Northcutt RC. Transsphenoidal removal of pituitary microadenoma in Cushing's disease. Mayo Clinic Proceedings $1978 \mathbf{5 3} 24-28$.

54 Imaki T, Tsushima T, Hizuka N, Odagiri E, Murata Y, Suda T \& Takano K. Postoperative plasma cortisol levels predict longterm outcome in patients with Cushing's disease and determine which patients should be treated with pituitary irradiation after surgery. Endocrine Journal 200148 53-62. (https://doi.org/10.1507/ endocrj.48.53)

55 Yap LB, Turner HE, Adams CBT \& Wass JAH. Undetectable postoperative cortisol does not always predict long-term remission in Cushing's disease: a single centre audit. Clinical Endocrinology 200256 25-31. (https://doi.org/10.1046/j.03000664.2001.01444.x)

56 Atkinson AB, Kennedy A, Wiggam MI, McCance DR \& Sheridan B. Long-term remission rates after pituitary surgery for Cushing's disease: the need for long-term surveillance. Clinical Endocrinology 200563 549-559. (https://doi.org/10.1111/j.13652265.2005.02380.x)

57 Acebes JJ, Martino J, Masuet C, Montanya E \& Soler J. Early postoperative ACTH and cortisol as predictors of remission in Cushing's disease. Acta Neurochirurgica 2007149 471-477. (https://doi. org/10.1007/s00701-007-1133-1)

Received 22 October 2017

Revised version received 14 December 2017

Accepted 8 January 2018 